\title{
Hubungan Pengetahuan tentang COVID-19 terhadap Kepatuhan Physical Distancing pada Mahasiswa Tingkat 4 FK UPNVJ
}

\section{Indah Permatasari $^{1^{*}}$, Tiwuk Susantiningsih ${ }^{2}$, Sri Wahyuningsih ${ }^{3}$}

${ }^{1}$ Program Studi Sarjana Kedokteran, Fakultas Kedokteran, Universitas Pembangunan Nasional Veteran Jakarta, Kota Jakarta Selatan, Indonesia

${ }^{2}$ Departemen Biokimia, Fakultas Kedokteran, Universitas Pembangunan Nasional Veteran Jakarta, Kota Jakarta Selatan, Indonesia

${ }^{3}$ Departemen Ilmu Kedokteran Komunitas dan Kesehatan Masyarakat, Fakultas Kedokteran, Universitas Pembangunan Nasional Veteran Jakarta, Kota Jakarta Selatan, Indonesia

*Corresponding Author. E-mail: indahp@gmail.com, Mobile number: +62 813-8778-9843

\begin{abstract}
ABSTRAK
Latar Belakang: Indonesia memiliki prevalensi COVID-19 yang cukup tinggi akibat rendahnya kepatuhan physical distancing. Penelitian ini bertujuan untuk mengetahui hubungan tingkat pengetahuan tentang COVID19 terhadap kepatuhan physical distancing pada mahasiswa tingkat 4 FK UPNVJ tahun 2020.

Metode: Penelitian ini menggunakan desain analitik observasional dengan pendekatan cross sectional. Sampel diambil secara simple random sampling.

Hasil: Analisis univariat memperlihatkan 67 responden (55.8\%) memiliki pengetahuan tentang COVID-19 yang baik dan 70 responden $(58.3 \%$ ) memiliki kepatuhan physical distancing yang baik. Uji chi square menunjukkan tidak ada hubungan bermakna antara tingkat pengetahuan tentang COVID-19 dengan kepatuhan physical distancing pada mahasiswa tingkat 4 FK UPNVJ tahun $2020(\mathrm{p}=0.203)$.

Kesimpulan: Tidak terdapat hubungan bermakna antara tingkat pengetahuan tentang COVID-19 dengan kepatuhan physical distancing pada mahasiswa tingkat 4 FK UPNVJ tahun 2020.
\end{abstract}

Kata Kunci: COVID-19; kepatuhan, pengetahuan,; physical distancing

Article history:

Received: 10 April 2021

Accepted: 30 April 2021

Published: 30 Juni 2021

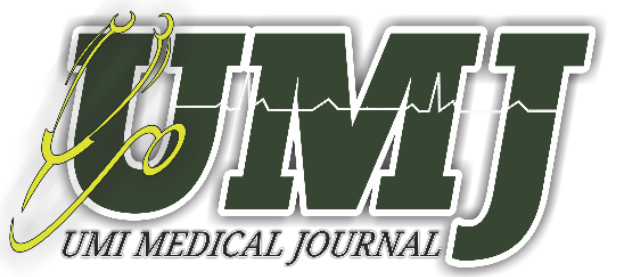

Published by :

Fakultas Kedokteran

Universitas Muslim Indonesia

Phone:

+6282293330002
Address:

Jl. Urip Sumoharjo Km. 5 (Kampus II UMI)

Makassar, Sulawesi Selatan.

Email:

medicaljournal@umi.ac.id 


\section{ABTRACT}

Background: Indonesia has a fairly high prevalence of COVID-19 due to low adherence towards physical distancing. The purpose of this study was to determine the relationship between knowledge level of COVID-19 and adherence of physical distancing among final year medical students of the FK UPNVJ in 2020.

Methods: This study used an observational analytic research design with a cross sectional approach. Simple random sampling was used for sampling method.

Results: Univariate analysis showed 67 respondents (55.8\%) had good knowledge of COVID-19 and 70 respondents $(58.3 \%)$ had good adherence to physical distancing. Chi square test showed there is no significant relationship between knowledge level of COVID-19 and adherence of physical distancing among final year medical students of FK UPNVJ in 2020 ( $\mathrm{p}=0.203)$.

Conclusion: There is no significant relationship between knowledge level of COVID-19 and adherence of physical distancing among final year medical students of FK UPNVJ in 2020.

Keywords: Adherence; COVID-19; knowledge; physical distancing

\section{PENDAHULUAN}

Coronavirus Disease 2019 (COVID-19) adalah penyakit menular yang disebabkan oleh Severe Acute Respiratory Syndrome Coronavirus 2 (SARS-CoV-2). ${ }^{1}$ Virus tersebut menimbulkan infeksi saluran pernafasan bawah yang dapat mengancam nyawa. Terhitung sejak diumumkannya kasus pertama pada 2 Maret 2020 sampai 1 Oktober 2020, terdapat 291,182 kasus terkonfirmasi di Indonesia. ${ }^{2}$ Hal tersebut $^{2}$ menjadikan Indonesia sebagai peringkat kedua negara dengan kasus terkonfirmasi COVID-19 terbanyak di Asia Tenggara. ${ }^{3}$

Salah satu faktor tingginya prevalensi COVID-19 di Indonesia adalah rendahnya kepatuhan masyarakat terhadap imbauan physical distancing. Physical distancing merupakan usaha untuk menjaga jarak terhadap orang lain secara fisik dalam rangka pencegahan penyebaran virus dari satu individu ke individu lain, dimana rekomendasi World Health Organization (WHO) untuk menjaga jarak adalah minimal 1 meter. ${ }^{4}$ Usaha tersebut sesuai untuk dilakukan mengingat karakteristik dari SARS-CoV-2 yang memiliki virulensi tinggi ${ }^{5}$ dan dan dapat bertransmisi pada fase presimptomatik. ${ }^{6}$

Ikatan struktur glikoprotein spike dari SARS-CoV-2 dengan reseptor Angiotensin Converting Enzyme 2 (ACE2) pada sel manusia sepuluh kali lebih kuat daripada ikatan glikoprotein spike dari SARSCoV lainnya. ${ }^{7}$ Hal ini disebabkan SARS-CoV-2 memiliki situs pembelahan furin polibasic pada batas Subunit 1 (S1) dan Subunit 2 (S2). ${ }^{8}$ Enzim furin akan membagi glikoprotein spike menjadi dua domain fungsional yaitu S1 dan S2. ${ }^{7}$ S1 pada glikoprotein spike berperan dalam proses penenpelan virus dengan reseptor ACE2 sementara S2 berperan dalam fusi antara virus dan membran seluler. ${ }^{9}$ Hal tersebut yang menyebabkan SARS-CoV-2 memiliki virulensi yang tinggi.

Studi potong lintang di Hubei, China menemukan bahwa tingginya tingkat pengetahuan mengenai COVID-19 berhubungan dengan praktik yang tepat dalam mencegah penularan COVID-19. ${ }^{10}$ Pengetahuan tentang COVID-19 harus diketahui semua orang termasuk mahasiswa kedokteran yang idealnya mengetahui tentang COVID-19 secara lebih dalam. Hal ini penting karena mahasiswa kedokteran akan 
UMI Medical Journal Vol.6 Issue:1 (Juni, 2021)

p-ISSN: 2548-4079/e-ISSN: 2685-7561

menjadi tenaga kesehatan yang tidak hanya bertugas untuk mencegah dirinya agar tidak tertular, tetapi juga sebagai sumber edukasi dan panutan bagi masyarakat lainnya. Praktik sehari-hari memperlihatkan imabuan physical distancing belum dilakukan secara baik, termasuk oleh mahasiswa kedokteran. Berdasarkan hal tersebut, peneliti bertujuan menganalisa hubungan tingkat pengetahuan tentang COVID19 terhadap kepatuhan physical distancing pada mahasiswa tingkat 4 Fakultas Kedokteran Universitas Pembangunan Nasional Veteran Jakarta.

\section{METODE}

Desain penelitian yang digunakan adalah analitik observasional dengan pendekatan cross sectional. Pengambilan data dilakukan dengan cara pengisian kuesioner secara online melalui google form. Penelitian dilakukan pada bulan September 2020 - Oktober 2020. Populasi penelitian adalah mahasiswa tingkat 4 FK UPNVJ tahun 2020 sebanyak 150 orang. Besar sampel ditentukan dengan perhitungan sampel untuk penelitian analisis kategorik tidak berpasangan. Setelah dihitung, diketahui sampel pada penelitian ini adalah 120 mahasiswa tingkat 4 FK UPNVJ tahun 2020 yang memenuhi kriteria inklusi dan eksklusi. Pengambilan sampel dilakukan dengan metode simple random sampling.

Instrumen pada penelitian ini menggunakan kuesioner berbentuk pertanyaan tertutup yang dibuat sendiri oleh peneliti untuk mendapatkan data primer. Kuesioner telah valid dan reliable dengan nilai alpha cronbach 0.702 untuk kuesioner pengetahuan tentang COVID-19 dan 0.829 untuk kuesioner kepatuhan terhadap imbauan physical distancing.

Data dianalisis dengan uji chi square untuk mengetahui hubungan antara variabel pengetahuan tentang COVID-19 dan variabel kepatuhan terhadap imbauan physical distancing. Penelitian ini telah menerima persetujuan etik untuk dilakukannya penelitian dari Komisi Etik Penelitian Kesehatan UPNVJ.

\section{HASIL}

Sampel penelitian adalah mahasiswa tingkat 4 FK UPNVJ yang berjumlah 120 orang.

Tabel 1. Disrtibusi Karakteristik Subjek Penelitian

\begin{tabular}{cccc}
\hline \multicolumn{2}{c}{ Karakteristik Subjek Penelitian } & N & \% \\
\hline \multirow{4}{*}{ Usia } & 20 & 35 & $29.2 \%$ \\
& 21 & 75 & $62.5 \%$ \\
& 22 & 9 & $7.5 \%$ \\
& 23 & 1 & $0.8 \%$ \\
& Total & $\mathbf{1 2 0}$ & $\mathbf{1 0 0 \%}$ \\
\hline \multirow{2}{*}{ Jenis Kelamin } & Laki-laki & 31 & $25.8 \%$ \\
& Perempuan & 89 & $74.2 \%$ \\
\hline Tingkat & Total & $\mathbf{1 2 0}$ & $\mathbf{1 0 0 \%}$ \\
Pengetahuan & Kurang & 53 & $44.2 \%$ \\
tentang COVID-19 & Baik & 67 & $55.8 \%$ \\
\hline Kepatuhan & Total & $\mathbf{1 2 0}$ & $\mathbf{1 0 0 \%}$ \\
Physical & Kurang & 50 & $41.7 \%$ \\
Distancing & Baik & 70 & $58.3 \%$ \\
& Total & $\mathbf{1 2 0}$ & $\mathbf{1 0 0 \%}$
\end{tabular}


UMI Medical Journal Vol.6 Issue:1 (Juni, 2021)

p-ISSN: 2548-4079/e-ISSN: 2685-7561

Data pada tabel 1 memperlihatkan sebagian besar responden pada penelitian ini berada pada kelompok usia 21 tahun $(62.5 \%)$ dan kelompok usia 23 tahun memiliki responden paling sedikit pada penelitian ini $(0.8 \%)$. Data diatas memperlihatkan sebagian besar responden pada penelitian ini memiliki jenis kelamin perempuan (74.2\%) dan hanya sebagian kecil dari responden memiliki jenis kelamin laki-laki (25.8\%).

Data pada tabel 1 juga memperlihatkan sebagian besar responden memiliki tingkat pengetahuan tentang COVID-19 yang baik (55.8\%) dan sebagian besar responden memiliki kepatuhan terhadap physical distancing yang baik (58.3\%).

Tabel 2. Hubungan Tingkat Pengetahuan tentang COVID-19 dengan Kepatuhan terhadap Physical Distancing pada Mahasiswa Tingkat 4 FK UPNVJ

\begin{tabular}{|c|c|c|c|c|c|c|c|c|c|}
\hline \multirow{3}{*}{$\begin{array}{c}\text { Pengetahuan } \\
\text { tentang COVID-19 }\end{array}$} & \multicolumn{4}{|c|}{ Kepatuhan Physical Distancing } & \multirow{2}{*}{\multicolumn{2}{|c|}{ Total }} & \multirow{3}{*}{$\begin{array}{c}\mathbf{p} \\
\text { value }\end{array}$} & \multirow{3}{*}{$\begin{array}{c}\text { Rasio } \\
\text { Prevalensi } \\
\text { (RP) }\end{array}$} & \multirow{3}{*}{$\begin{array}{c}\text { Interval } \\
\text { Kepercayaan } \\
95 \%\end{array}$} \\
\hline & \multicolumn{2}{|c|}{ Baik } & \multicolumn{2}{|c|}{ Kurang } & & & & & \\
\hline & $\mathbf{N}$ & $\%$ & $\mathbf{N}$ & $\%$ & $\mathbf{N}$ & $\%$ & & & \\
\hline Baik & 43 & $64.2 \%$ & 24 & $35.8 \%$ & 67 & $100 \%$ & \multirow{3}{*}{0.203} & \multirow{3}{*}{1.260} & \multirow{3}{*}{$\begin{array}{l}0.916 \\
-1.733\end{array}$} \\
\hline Kurang & 27 & $50.9 \%$ & 26 & $49.1 \%$ & 53 & $100 \%$ & & & \\
\hline Total & 70 & $58.3 \%$ & 50 & $41.7 \%$ & 120 & $100 \%$ & & & \\
\hline
\end{tabular}

Data pada tabel 2 memperlihatkan baik responden dengan pengetahuan tentang COVID-19 yang baik (64.2\%) dan responden dengan pengetahuan tentang COVID-19 yang kurang (50.9\%), sebagian besar memiliki kepatuhan terhadap physical distancing yang baik.

Uji chi square memperlihatkan bahwa tidak ada hubungan bermakna antara tingkat pengetahuan tentang COVID-19 dengan kepatuhan terhadap physical distancing pada mahasiswa tingkat 4 FK UPNVJ $(\mathrm{p}=0.203)$.

Data pada tabel 2 juga memperlihatkan bahwa mahasiswa tingkat 4 FK UPNVJ dengan pengetahuan tentang COVID-19 yang baik mempunyai kemungkinan 1.260 kali untuk memiliki kepatuhan terhadap physical distancing yang baik $(\mathrm{RP}=1.260)$. Namun, pengetahuan tentang COVID-19 belum dapat dikatakan secara definitif sebagai faktor dari kepatuhan terhadap physical distancing pada mahasiswa tingkat 4 FK UPNVJ (IK 95\% = $0.916-1.733)$.

\section{PEMBAHASAN}

\section{Pengetahuan tentang COVID-19}

Hasil penelitian ini menunjukkan bahwa 67 orang (55.8\%) memiliki pengetahuan tentang COVID19 yang baik dan 53 orang (44.2\%) memiliki pengetahuan tentang COVID-19 yang kurang. Hasil tersebut serupa dengan penelitian yang dilakukan Winarti dan Hartati (2020) yang memperlihatkan dari 110 mahasiswa, 62 mahasiswa (56,4\%) mempunyai pengetahuan tentang COVID-19 yang baik dan 48 mahasiswa (43,6\%) mempunyai pengetahuan tentang COVID-19 kurang. ${ }^{11}$

Penelitian ini memperlihatkan sebagian besar responden memiliki tingkat pengetahuan tentang COVID-19 yang baik. Hal tersebut dapat disebabkan karena saat ini telah tersedia banyak media yang dapat menjadi sumber informasi mengenai COVID-19, seperti media sosial, internet, televisi ataupun surat 
UMI Medical Journal Vol.6 Issue:1 (Juni, 2021)

p-ISSN: 2548-4079/e-ISSN: 2685-7561

kabar. ${ }^{12}$ Selain itu, tingginya pengetahauan tentang COVID-19 dapat disebabkan karena mahasiswa kedokteran telah dilatih mengenai pengetahuan klinis dan kesehatan masyarakat. ${ }^{13}$ Mahasiswa kedokteran juga memiliki pemahaman yang lebih baik mengenai informasi general tentang COVID-19 karena mahasiswa kedokteran cenderung memperbarui pengetahuan medis mereka tentang COVID-19 dari artikel penelitian, media akademik, dan perkuliahan. ${ }^{14}$

Mahasiswa FK UPNVJ dalam perjalanan studinya telah mempelajari berbagai aspek yang diperlukan dalam dunia kedokteran, mulai dari ilmu kedokteran dasar sampai dengan ilmu kedokteran berbasis sistem. Berkaitan dengan patogenesis dan patofisiologi dari COVID-19, ilmu biokimia dasar merupakan salah satu aspek penting dalam memahami bagaimana COVID-19 menginfeksi manusia. Pemahaman yang baik mengenai patogenesis dan patofisiologi dari COVID-19 dapat meningkatkan pengetahuan mahasiswa mengenai COVID-19.

\section{Kepatuhan terhadap physical distancing}

Hasil penelitian menunjukkan bahwa 70 orang (58.3\%) memiliki kepatuhan terhadap physical distancing yang baik dan 50 orang (41.7\%) memiliki kepatuhan terhadap physical distancing yang kurang. Hasil tersebut serupa dengan penelitian yang dilakukan Taghrir, Borazjani dan Shiraly (2020) yang memperlihatkan dari 240 mahasiswa kedokteran, terdapat 226 responden (94.2\%) memiliki perilaku preventif baik terhadap COVID-19 dan hanya 14 responden (5.8\%) yang memiliki perilaku preventif kurang baik terhadap COVID-19. ${ }^{15}$

Penelitian ini memperlihatkan sebagian besar responden memiliki kepatuhan terhadap physical distancing yang baik. Hal tersebut dapat disebabkan sebagian besar responden penelitian ini adalah perempuan dan sebagian besar responden berada pada kelompok usia usia 21 tahun. Responden dengan jenis kelamin perempuan dan kelompok usia diatas 20 tahun memiliki kecemasan yang tinggi akan kemungkinan tertular COVID-19, sehingga cenderung memiliki kepatuhan terhadap physical distancing yang baik. ${ }^{16}$

Sebagian besar responden memiliki kepatuhan terhadap physical distancing yang baik juga dapat disebabkan karena mahasiswa kedokteran lebih familiar dengan anjuran kesehatan, sehingga terdapat perasaan mampu untuk mengikutinya. Selain itu, mahasiswa kedokteran cenderung berasal dari latarbelakang sosioekonomi yang tinggi, sehingga lebih patuh terhadap imbauan physical distancing dibanding orang yang berlatarbelakang sosioekonomi rendah. ${ }^{17}$

Mahasiswa kedokteran yang idealnya memiliki pemahaman lebih mendalam mengenai suatu penyakit terutama berkaitan dengan patogenesis dan patofisiologinya juga dapat mendukung praktik pencegahan yang lebih baik. Berkaitan dengan patogenesis dan patofisiologi COVID-19, SARS-CoV-2 memiliki struktur dengan karakteristik yang dapat memudahkan penularan dan menimbulkan manifestasi 
UMI Medical Journal Vol.6 Issue:1 (Juni, 2021)

p-ISSN: 2548-4079/e-ISSN: 2685-7561

klinis yang berat dari COVID-19. Hal tersebut memicu praktik physical distancing yang baik dari responden penelitian ini.

\section{Hubungan tingkat pengetahuan tentang COVID-19 dengan kepatuhan terhadap physical distancing}

Penelitian ini menunjukkan tidak ada hubungan bermakna antara tingkat pengetahuan tentang COVID-19 dengan kepatuhan terhadap physical distancing pada mahasiswa tingkat 4 FK UPNVJ $(p=$ 0.203). Penelitian ini sejalan dengan penelitian Mudawaroch (2020) yang menuunjukkan bahwa pengetahuan tidak mempengaruhi perilaku mahasiswa menghadapi virus corona $(\mathrm{p}=0.076) .{ }^{18}$ Hasil penelitian ini juga sejalan dengan penelitian Syadidurrahmah, dkk (2020) yang memilik hasil tidak ditemukan hubungan bermakna antara pengetahuan mengenai COVID-19 dengan perilaku physical distancing pada Mahasiswa UIN Syarif Hidayatullah Jakarta $(\mathrm{p}=0.875) .{ }^{19}$ Namun penelitian Zulhafandi dan Ariyanti (2020) menunjukkan hasil berbeda, penelitian tersebut memperlihatkan adanya hubungan antara tingkat pengetahuan tentang COVID-19 dengan kepatuhan melakukan physical distancing di kota Tarakan $(\mathrm{p}=0.00) .^{20}$

Tidak adanya hubungan antara tingkat pengetahuan tentang COVID-19 dengan kepatuhan terhadap physical distancing disebabkan karena kepatuhan terhadap physical distancing tidak hanya ditentukan oleh satu faktor saja. Faktor lain seperti faktor sosiokultural juga dapat mempengaruhi kepatuhan terhadap physical distancing.

Faktor sosiokultural pada penelitian ini terlihat dari responden yang merupakan mahasiswa kedokteran, sehingga orang yang ada di lingkungan sekitar seperti keluarga dan kerabat pada umumnya akan memiliki ekspektasi lebih tinggi terhadap mahasiswa kedokteran mengenai praktik physical distancing yang lebih baik. Hal tersebut dapat mendorong kepatuhan terhadap physical distancing yang baik dari diri sendiri dengan harapan perilaku tersebut dapat menjadi contoh dan ikut dilakukan oleh keluarga dan kerabat yang ada disekitar. Selain itu, mahasiswa kedokteran juga merasa memiliki kewajiban dan tanggung jawab untuk memerangi pandemi sebagai calon tenaga kesehatan medis dimasa depan, sehingga terdorong untuk menunjukkan sikap yang lebih positif dan praktik proaktif selama keadaan darurat kesehatan masyarakat ini. ${ }^{13}$

Pelaksanaan physical distancing hanya akan efektif bila sebagian besar masyarakat ikut patuh. ${ }^{17}$ Faktor sosiokultural dalam lingkungan pertemanan sesama mahasiswa kedokteran membuat responden melihat dan meniru perilaku yang dilakukan sesama mahasiswa kedokteran lainnya, yaitu patuh terhadap physical distancing.

Banyaknya imbauan di media massa mengenai pentingnya praktik physical distancing dari berbagai elemen publik mulai dari pemerintahan, publik figur hingga perkumpulan tertentu seperti Ikatan Dokter Indonesia (IDI) dapat membuat mahasiswa kedokteran ingin lebih dapat ikut andil dalam melakukan praktik physical distancing yang baik. Selain itu, lingkungan di FK UPNVJ yang memiliki respon positif 
UMI Medical Journal Vol.6 Issue:1 (Juni, 2021)

p-ISSN: 2548-4079/e-ISSN: 2685-7561

terhadap usaha pencegahan COVID-19 juga dapat berpengaruh terhadap kepatuhan mahasiswa kedokteran terhadap physical distancing. Budaya saling mengingatkan untuk selalu menerapkan praktik physical distancing yang dilakukan antar dosen, mahasiswa dan civitas akademika lain secara tidak langsung dapat mempengaruhi kepatuhan mahasiswa kedokteran terhadap physical distancing.

\section{KESIMPULAN}

Tidak ada hubungan bermakna antara tingkat pengetahuan tentang COVID-19 terhadap kepatuhan physical distancing pada mahasiswa tingkat 4 FK UPNVJ tahun 2020.

\section{SARAN}

Walaupun sebagian besar responden telah memiliki pengetahuan tentang COVID-19 dan kepatuhan physical distancing yang baik, pembaharuan pengetahuan tentang COVID-19 dari berbagai sumber dan peningkatan kepatuhan physical distancing harus terus dilakukan agar mahasiswa dapat memberikan edukasi dan dorongan kepada masyarakat mengenai pentingnya pelaksanaan physical distancing. Penelitian berkelanjutan mengenai faktor-faktor lain yang dapat mempengaruhi physical distancing dapat dilakukan mengingat kualitas pelaksanaan physical distancing merupakan salah satu indikator pencegahan dari penularan COVID-19.

\section{DAFTAR PUSTAKA}

1. Sohrabi C, Alsafi Z, O’Neill N, Khan M, Kerwan A, Al-Jabir A, et al. World Health Organization declares global emergency: A review of the 2019 novel coronavirus (COVID-19). Int J Surg [Internet]. 2020;76(February):71-6. Available from: https://doi.org/10.1016/j.ijsu.2020.02.034

2. Gugus Tugas Percepatan Penanganan COVID-19. Peta Sebaran [Internet]. 2020. Available from: https://covid19.go.id/peta-sebaran

3. ASEAN Biodiaspora Virtual Center (ABVC). Risk Assessment for International Dissemination of COVID-19 to the ASEAN Region. 2020;2020. Available from: https://asean.org/storage/2020/02/BioDiaspora-16-COVID-19-Risk-Assessment_ASEANBioDiaspora-Regional-Virtual-Center_06Mar2020.pdf

4. World Health Organization. Coronavirus disease (COVID-19) advice for the public [Internet]. 2020. Available from: https://www.who.int/emergencies/diseases/novel-coronavirus-2019/advicefor-public

5. Wrapp D, Wang N, Corbett KS, Goldsmith JA, Hsieh CL, Abiona O, et al. Cryo-EM structure of the 2019-nCoV spike in the prefusion conformation. Science (80- ). 2020;367(6483):1260-3.

6. Nishiura H, Linton NM, Akhmetzhanov AR. Serial interval of novel coronavirus (COVID-19) infections. Int J Infect Dis [Internet]. 2020;93:284-6. Available from: https://doi.org/10.1016/j.ijid.2020.02.060 
p-ISSN: 2548-4079/e-ISSN: 2685-7561

7. Takuma H, Takashi U, Kaoru A, Masaki M, Nobuo Y, Ikuo K. Reasons why new coronavirus, SARS-CoV-2 infections are likely to spread. J Genet Med Gene Ther. 2020;3(1):001-3.

8. Walls AC, Park YJ, Tortorici MA, Wall A, McGuire AT, Veesler D. Structure, Function, and Antigenicity of the SARS-CoV-2 Spike Glycoprotein. Cell [Internet]. 2020;181(2):281-292.e6. Available from: http://dx.doi.org/10.1016/j.cell.2020.02.058

9. Hoffmann M, Kleine-Weber H, Schroeder S, Krüger N, Herrler T, Erichsen S, et al. SARS-CoV-2 Cell Entry Depends on ACE2 and TMPRSS2 and Is Blocked by a Clinically Proven Protease Inhibitor. Cell. 2020;181(2):271-280.e8.

10. Zhong BL, Luo W, Li HM, Zhang QQ, Liu XG, Li WT, et al. Knowledge, attitudes, and practices towards COVID-19 among Chinese residents during the rapid rise period of the COVID-19 outbreak: a quick online cross-sectional survey. Int J Biol Sci. 2020;16(10):1745-52.

11. Winarti R, Hartati S. Kajian Pengetahuan Mahasiswa AKPER Hermina Manggala Husada tentang COVID 19 dan Cara Pencegahannya. J Ilm Keperawatan Altruistik. 2020;3(2):1-9.

12. Usman S, Budi S, Nur Adkhana Sari D. Pengetahuan Dan Sikap Mahasiswa Kesehatan Tentang Pencegahan COVID-19 Di Indonesia. J Ilmu Keperawatan dan Kebidanan [Internet]. 2020;11(2):258-64. Available from: Pengetahuan Dan Sikap Mahasiswa Kesehatan Tentang Pencegahan Covid-19 Di Indonesia

13. Peng Y, Pei C, Zheng Y, Wang J, Zhang K, Zheng Z, et al. Knowledge, Attitude and Practice Associated with COVID-19 among University Students: a Cross-Sectional Survey in China. BMC Public Health. 2020;20:1-8.

14. Gao Z, Ying S, Liu J, Zhang H, Li J, Ma C. A cross-sectional study: Comparing the attitude and knowledge of medical and non-medical students toward 2019 novel coronavirus. J Infect Public Health [Internet]. 2020;4-8. Available from: https://doi.org/10.1016/j.jiph.2020.06.031

15. Taghrir MH, Borazjani R, Shiraly R. COVID-19 and iranian medical students; A survey on their related-knowledge, preventive behaviors and risk perception. Arch Iran Med [Internet]. 2020;23(4):249-54. Available from: https://doi.org/10.34172/aim.2020.06

16. Olaimat AN, Aolymat I, Elsahoryi N, Shahbaz HM, Holley RA. Attitudes, Anxiety, and Behavioral Practices Regarding COVID-19 among University Students in Jordan: A Cross-Sectional Study. Am J Trop Med Hyg. 2020;103(3):1177-83.

17. Jørgensen FJ, Bor A, Petersen MB. Compliance Without Fear: Predictors of Protective Behavior During the First Wave of the COVID-19 Pandemic. 2020;1-62.

18. Mudawaroch RE. Pengaruh Pengetahuan dan Sikap Terhadap Perilaku Mahasiswa Mengahadapi Virus Corona. Pros Hukum, Bisnis, Sains dan Teknol. 2020;147(1):257-63.

19. Syadidurrahmah F, Muntahaya F, Islamiyah SZ, Fitriani TA. Perilaku Physical Distancing 
UMI Medical Journal Vol.6 Issue:1 (Juni, 2021)

p-ISSN: 2548-4079/e-ISSN: 2685-7561

Mahasiswa UIN Syarif Hidayatullah Jakarta pada Masa Pandemi COVID-19. Indones J Heal Promot Behav. 2020;2(1):29-37.

20. Zulhafandi, Ariyanti R. Hubungan Pengetahuan tentang COVID-19 dengan Kepatuhan Physical Distancing di Tarakan. J Kebidanan Mutiara Mahakam. 2020;8(2):102-11. 